\title{
軌道の動力学的强度について
}

\author{
正員小野 一 艮
}

\section{DYNAMICAL STRESSES AND STRAINS IN RAILS AND IN OTHER TRACK MATERIALS}

\author{
Kazuyoshi Ono, C.E. Member
}

\begin{abstract}
Synopsis The dynamical deflection of the rail and the dynamical stresses under the action of the moving wheels may become much larger than those calculated on the basis of the static formula. There are various causes which may produce such an increase in deflection and stress, some of which are discussed in three groups, a, b and $\mathrm{c}$.
\end{abstract}

(a) Variation in the forces acting on the rail caused by variable spring forces on the wheel; the vertical component of the centrifugal force of the counterweights and the vertical component of the torces in the connecting rods.

(b) Different kinds ot irregularities in the shape of the wheel or rail, such as flat spots on the rim, low spots on the rail and discontinuities at the rail joints.

(c) Inertia force and internal friction of the track materials and the road bed accompanying with their vertical motion under moving loads. In discussing the causes mentioned in (a) it should be noted that their effect on the deflections and stresses in the rails can be calculated without substantial error in a statical way.

In this paper a method is developed for calculating the increase in deflections and stresses produced by the causes mentioned in (c).

\section{目次}

第 1 篇 走行荷重に依る軌道の撓み運動

1. 緒 言

2. 軦道上部の質量がレールに集中する場合

3. 深さ有限の彈性築堤上にある長さ無限の梁

4. 実験值と計算值との比較

5. 深さ無限の彈性築堤上にある長さ無限の梁

6. 結 論

\section{1. 緒}

静荷重に依つて軌道の各部分に生ずる応力及び変形の計算方法に関しては略完全な理論が岕り，実測にも一致 している。然るに動荷重の場合には次の各種の原因に依つて軌道に生ずる応力及び夜形が增減する。

（a）車輛の動摇に伴 らバネの伸縮，機関車の釣合鏵の一部（前後の徍復運動をなす質量に釣合わせるためつ けた部分)に依る遠心力，主連棒に加わる力の垂直分力。

(b)”車輪踏面及びレール面にある不整（レールの継目を含む）に体つて生ずる㣫撃。

(c) 軌道及び路盤の撓み運動に於ける軌道及び路盤自身の慣性の影響; 軌道及び路船の変形に伴 5 内部摩擦 の影響。”

從来はこれ等すべての影響を総括して衝撃と称し，衝撃の大きさは静荷重の大きさ反び列車速度に比例すると 見做して計算しホ。然し軌道の動力学的強度を検討するにはこれ等各種の原因に依る影響を分けて研究する要が ๘る。

（a）の原因に依る影響は力の変動する周期が車輛及び軌道の振動に比し比較的に゙長いのでこれを静荷重として 計算しても殆ど誤りはない。本書に於ては主として（c）の原因に依る影響学諭ずることつし，(b) の原因に体 る影響については第2 篇に論ずる予定である。

從来 (c)の影響を考慮に入れて計算する方法が 2,3 発表せられて特り*1, これ等の諭交はすべて次の仮定を 設けて括り，との仮定に依る計算方法を第 2 章に示す。

(i) 上下動をなす軌道 (レール，枕木及び一部の道床砂利）の質量が全部レールに集中すると仮定し，弾性 床自身は質量を持をないとする。 
(ii) 軌道の上下運動に伴 5 軌道の摩擦抵抗力は運動の速度に比例する。

然るに動荷重に伡つて上下運動をなすのはレール，枕木だけでなく，その質量から見て道床及び路盤が大きな

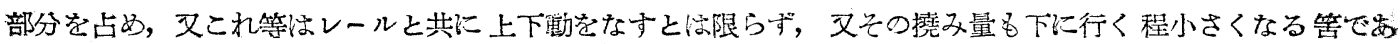
る。從つて全部の質量がレールに集中すると仮定すること㑏適当でない。

軌道の摩擦抵抗力撓み運動の速度に比例すると見ること淰流体内に固体が運動する場合から類推したものと 思われるが，軌道の摩擦抵抗力怯蓋ろ変形の速度に比例すると見るべきである。

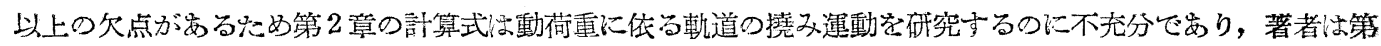
3 章以下に弾性床自身の慣性及び変形代対する抵抗力を考虑に入れた場合の弾性床上にある梁の撓み運動の計算. 方法を述べ害測值と刘照することとした。

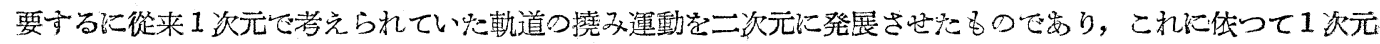
では説明出来なかつを種々の事害を説明することが出来，走行荷重に対する喠道の性質を明かになし得を。

\section{2. 軌道上部の質量がレールに集中する場合}

前章に述べを仮定 (i), (ii) を使えぱレールの撓多運動に関して次の式が成立つ。

$$
E J \frac{\partial^{4} y}{\partial x^{4}}+\frac{m}{g} \frac{\partial^{2} y}{\partial t^{2}}+R \frac{\partial y}{\partial t}+K y=0
$$

上式に执いて $E$ はレールのヤンダ倸数，J洁レールの断面2 次モーメ ント，m はレールに集中ーると仮定したレール，枕木及び道休上部の単 位長さ当りの質量とする。 $R$ はレールの撓み蓮動の単位速度に対する軌 道単位長さ当りの摩擦抵抗力 $\left(\mathrm{kgsec} / \mathrm{cm}^{2}\right)$ であり, $K$ 隹弾性床の単位沈 年量に対する轨道単位長さ当りの反力 $\left(\mathrm{kg} / \mathrm{cm}^{2}\right)$ でり, 以後弾性床の基

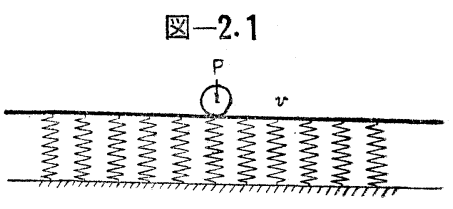

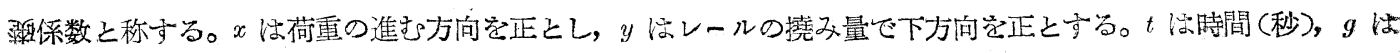
重力の加速度とする。

(2.1) 式空間に固定した座標に於ける式で岀るが，荷重の走行速度 $v(\mathrm{~cm} / \mathrm{sec})$ を一定と考光て街重と共に

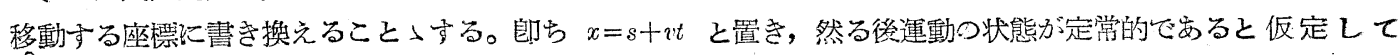
$\frac{\partial w}{\partial t}=0$ とする。この時 $y$ は $s$ のの函数となり，(2.1) 式は次の如くなる。

$$
E J \frac{d^{4} y}{d s^{4}}+\frac{m}{g} v^{2} \frac{d^{2} y}{d s^{2}}-R v \frac{d y}{d s}+K y=0
$$

この微分方程式を解くに当り次の諸条件を考慮与る。

(a) $s \leqq 0$ に於て $y=y_{1}$ とし, $s \rightarrow-\infty$ に於て $x_{1} \neq \infty$

(b) $s \geqq 0$ に於て $y=y_{2}$ とし, $s \rightarrow \infty$ に於て $y_{1} 甘+\infty$

(c) $s=0: y_{1}=y_{2}, y_{1}{ }^{\prime}=y_{2}{ }^{\prime}, y_{1}{ }^{\prime \prime}=y_{2}{ }^{\prime \prime}$

(d) $s=0$ の位置に荷重 $P(\mathrm{~kg})$ が女るとして

$$
s=0: E J_{y_{1}}{ }^{\prime \prime \prime}+P=E J_{y_{2}}{ }^{\prime \prime \prime}
$$

然る時は

$$
\left.\begin{array}{l}
y_{1}=\exp (\alpha s)\left(A \cos \beta_{1} s+B_{1} \sin \beta_{1} s\right) \\
y_{2}=\exp (-\alpha s)\left(A \cos \beta_{2} s+B_{2} \sin \beta_{2} s\right)
\end{array}\right\}^{* 2}
$$

但し $\alpha, \beta_{1}, \beta_{2}$ 忟次式に依つて計算される正の実数であり， $A, B_{1}, B_{2}$ は (2.7) 式に依つて計算される。

$$
\begin{aligned}
& \alpha^{2}\left\{\left(\alpha^{2}+\frac{m v^{2}}{4 E J g}\right)^{2}-\frac{K}{4 E J}\right\}=\frac{1}{4}\left(\frac{R v}{4 E J}\right)^{2} \\
& \beta_{1}^{2}=\alpha^{2}+2 \frac{m v^{2}}{4 E J g}-\frac{R v}{4 E J} \frac{1}{\alpha} \\
& \beta_{2}{ }^{2}=\alpha^{2}+2 \frac{m v^{2}}{4 E J g}+\frac{R v}{4 E J} \frac{1}{\alpha} \\
& A=\frac{P}{E J} \cdot \frac{\alpha}{8 \alpha^{2}\left(\alpha^{2}+\frac{m v^{2}}{4 E J g}\right)+\left(\frac{R v}{4 E J} \frac{1}{\alpha}\right)^{2}} \\
& B_{1}=-\frac{P}{E J} \cdot \frac{\alpha^{2}+\frac{1}{2} \frac{R v}{4 E J} \frac{1}{\alpha}}{\beta_{1}\left\{8 \alpha^{2}\left(\alpha^{2}+\frac{m v^{2}}{4 E J g}\right)+\left(\frac{R v}{4 E J g} \frac{1}{\alpha}\right)^{2}\right\}}
\end{aligned}
$$




$$
\left.B_{2}=\frac{P}{E J} \cdot \frac{\alpha^{2}-\frac{1}{2} \frac{R v}{4 E J} \frac{1}{\alpha}}{\beta_{2}\left\{8 \alpha^{2}\left(\alpha^{2}+\frac{m v^{2}}{4 E J g}\right)+\left(\frac{R v}{4 E J} \frac{1}{\alpha}\right)^{2}\right\}}\right\}
$$

上式に示すよ5に一般に荷重の前方に於けるレールの撓み曲線と荷重の後方に於けるものは形が異つている。 荷重の速度が特に大きくない時には一般に次の関係がある。

$$
\frac{m v^{2}}{4 E J g \kappa^{2}} \ll 1, \quad \frac{R v \kappa}{K_{1}} \ll 1 \text { 但乙 } \kappa=\sqrt[4]{\frac{K}{4 E J}}
$$

この時法 $s=0$ に於けるレールの撓み量 $y_{0}$, レール面の傾斜看 $\theta_{0}$, レールに生ずる曲げモーメント $M_{0}$ 快次 式化依つて計算される。

$$
\begin{aligned}
& y_{0}=\frac{P}{8 E J_{K^{3}}}\left\{1+\frac{1}{8 E J_{\kappa^{2}}}\left(\frac{m}{g}-\frac{5 R^{2}}{8 K}\right) v^{2}\right\} \\
& \tan \theta_{0}=\frac{P R v}{16 E J_{\kappa} K} \\
& M_{0}=\frac{P}{4 \kappa}\left\{1+\frac{1}{8 E J_{\kappa^{2}}}\left(\frac{m}{g}-\frac{3 R^{2}}{8 K}\right) v^{2}\right\}
\end{aligned}
$$

上式上り見られるよらに $s=0$ に於けるレール面の傾斜角は 0 とはならず,レールの最大捖み量壳生ずる位 置は走行荷重の少し後方比岕る。この撓々量を $y_{\max }$ 之寸れば

$$
y_{\max }=\frac{P}{8 E J_{\kappa^{3}}}\left\{1+\frac{1}{8 E J_{\kappa^{2}}}\left(\frac{m}{g}-\frac{R^{2}}{2 K}\right) v^{2}\right\}
$$

(2.9)，(2.10) 式上り見られるよ5に $y_{0} ， y_{\max }, M_{0}$ はレール，枕木等の慣性长依つて增加し，摩擦抵抗力の

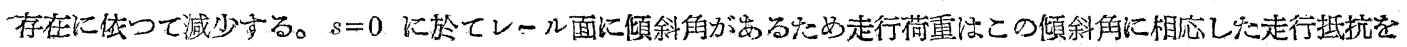

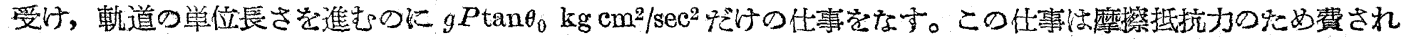
るのである。

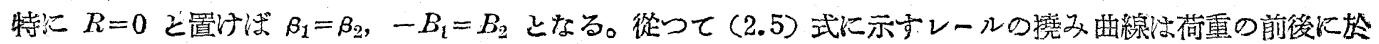
て対称となり， $\tan \theta_{0}=0$ となる。

次に $R=0$ とし，慣性の影響を $50 \mathrm{~kg}$ レール敷設の線路について計算する。 $J=1744 \mathrm{~cm}, K=390 \mathrm{~kg} / \mathrm{cm}^{2}$ と し， $m$ としてはレール，枕木及び道床砂利上部の質量を考慮し $6 \mathrm{~kg} / \mathrm{cm}$ とする。(2.8) 式に依れば $\kappa=0.0128$ となり，(2.9）式に依ればレールの撓み量及び曲げモーメントの速度に传る增加率洁流一1 の如くなる。

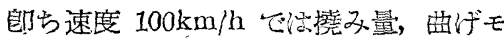
ーメント共に静荷重の $1 \%$ 増しであり, 殆 ど問題にならない。

次に $m=0$ と置いて摩擦抵抗力口影響の みを調べることつする。(2.5), (2.6)，(2.7) 式に於て

$$
\kappa=\sqrt[4]{\frac{K}{4 E J}}, \quad f=\frac{R_{v}}{8 E J \kappa^{3}}, \quad y=\frac{P}{8 E J \kappa^{3}} y^{\prime *}
$$

\section{図 -2.2}

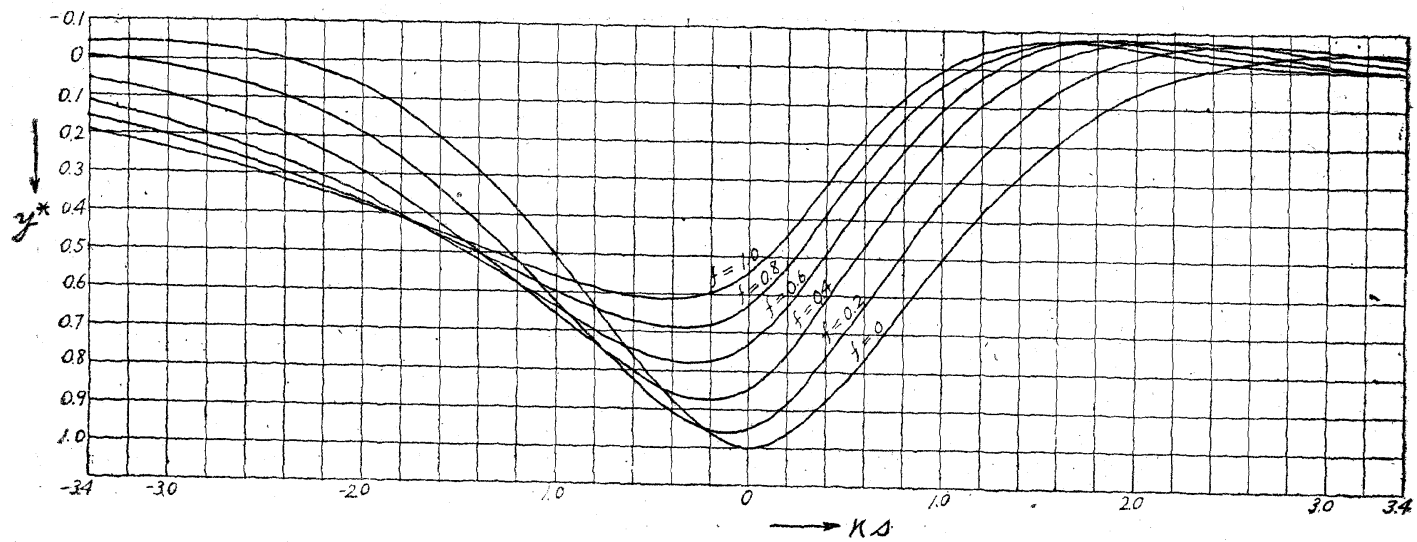


と置いて種々の $f$ の值に対して $s$ と $y^{\prime *}$ との関係を計算寸れば 図-2.2 の如くなる。 $f$ の值が大きくなるに 從い荷重の前力に於ける撓み曲線の勾配は急になり, 何重の後方の勾配 は緩やかになつている。これ等の最急勾配を

$$
\left|\frac{d y}{d s}\right|_{\max }=\frac{P}{8 E J_{\kappa^{2}}} y^{\prime *}
$$

と置いて $f$ と $y^{*}$ との関係を画けば 図一2.3 の如くなる。図-2.3 に於て $f>0$ の部分嗬重の前方に於ける最急勾配学示し, $f<0$ の部 分深荷重の啳方に於ける最急勾配を示す。

\section{3. 深さ有限の彈性築堤上にある長さ無限の梁}

第 2 章でば軌道反び路盤の質量が 1 平面上に集中すると仮定して走行 荷重に依る軌道の撓々運動を論じたのであるが，実際は荷重の通過に伴 つて生ずる上下運動が路盤の表面から内部に伝播するのであつて, 質量 が集中すると仮定した場合に比較して運動の様相が非常 に異るであろちことは想像に難くない。

次に軌道を弾性体の築堤上に岕る長さ無限の梁として 走行荷重に依る運動の状態を明かにする。レール，枕木 等の質量も弾性体の質量の一部構成していると考える。 築堤の高さを $h$ とし, 築堤の幅 $2 b$ は深さ $z$ の增すに 從い次式に示す形厄増すこと〉する。

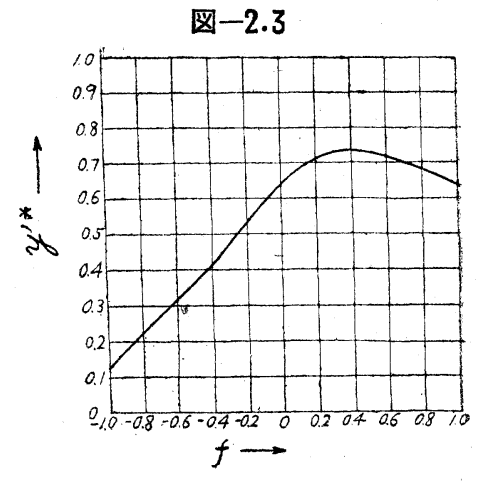

図-3.1

$$
2 b=2 b_{0} \exp (2 \psi z)
$$
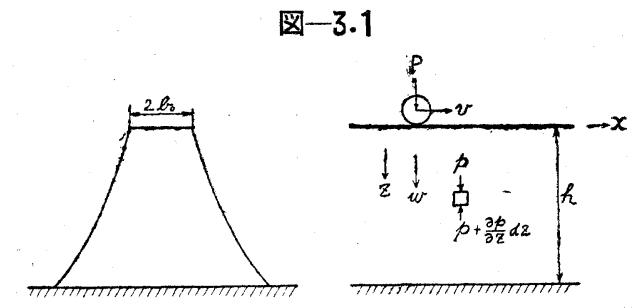

こ〉に $2 b_{0}$ 你深さ 0 に蚂ける路盤の幅とする。築堤以外の線路に於てる轨道上部の圧力は深さの増すに伴、 広く路盤に分布するので上式を適用し得る。路盤下層に堅い地盤がある時はそれまでの深さを彭とし，全部が 均等な地層であれば $h$ をゅとする。但し $h$ がゅとなる時の計算方法は第 5 章に示す。

路盤を構成する地層は圧縮と剪断に対して抵抗を持つのであるが，実験結果に传れば剪断に対する抵抗力は無 視して差吝えないので，篧に対する抵抗力のみを考慮すること入する。

弾性体の単位体積当りの質量を $\rho\left(\mathrm{kg} / \mathrm{cm}^{3}\right)$ とし, 圧縮に対する弾性係数を $k\left(\mathrm{~kg} / \mathrm{cm}^{2}\right)$ とする。 $k$ は材料のヤ ング係数 $E^{\prime}$ ポアソン比 $\sigma$ と次の関係にある。

$$
k=\frac{1-\sigma}{(1+\sigma)(1-2 \sigma)} E^{\prime}
$$

路盤の内部摩擦は変形の速度に比例するとし，比例の常数を $\gamma\left(\mathrm{kgsec} / \mathrm{cm}^{2}\right)$ とする。

路盤内の圧力を $p\left(\mathrm{~kg} / \mathrm{cm}^{2}\right)$ とし， $z$ 軸を軌条面から下方に採る。又路盤内の $(x, z)$ に於ける撓み量を $w$ とす る。然る時は

$$
p=-k \frac{\partial w}{\partial z}-\gamma \frac{\partial^{2} w}{\partial z \partial t}
$$

又路盤の幅の方向に於ける圧力を一定と仮定すれば,

$$
b \rho \frac{\partial^{2} w}{\partial t^{2}}=-g \frac{\partial}{\partial z}(b p)
$$

上式の $w$ は空間に固定した座標に依る式であるが，荷重の速度 $v$ 】定とし， $x=s+\imath t$ と置いて $w$ を荷重 と共に動く座標に書き換えること〉する。軌道及び路盤の撓み運動が定常状態に達したとすれば, (3. 3), (3.4) 式に於ける $\frac{\partial w}{\partial t}$ は $-v \frac{\partial w}{\partial s}$ を以て置き提えられ, 從つて

$$
\begin{aligned}
& p=-k \frac{\partial w}{\partial z}+\gamma v \frac{\partial^{2} w}{\partial s \partial z} \\
& b \rho v^{2} \frac{\partial^{2} w}{\partial s^{2}}=-g \frac{\partial}{\partial z}(b p)
\end{aligned}
$$

(3.6) 式の $b$ 及び $p$ に (3.1) 及び (3.5) 式を代入すれば

$$
\rho v^{2} \frac{\partial^{2} w}{\partial s^{2}}=g k\left(2 \psi \frac{\partial w}{\partial z}+\frac{\partial^{2} w}{\partial z^{2}}\right)-g \gamma v\left(2 \psi \frac{\partial^{2} w}{\partial s \partial z}+\frac{\partial^{3} w}{\partial s \partial z^{2}}\right)
$$

上式を解くために 


$$
w=\exp (\lambda s+\mu z)
$$

と置けば

$$
\rho v^{2} \lambda^{2}=g(k-\gamma v \lambda)\left(2 \psi \mu+\mu^{2}\right)
$$

上式を解けば 1 個の $\lambda$ に対し 2 個の $\mu$ が得られ，これを $\mu_{1}, \mu_{2}$ とする。包ら

$$
\left.\begin{array}{l}
\mu_{1}=-\psi+\sqrt{\psi^{2}+\frac{\rho v^{2} \lambda^{2}}{g(k-\gamma v \lambda)}} \\
\mu_{2}=-\psi-\sqrt{\psi^{2}+\frac{\rho v^{2} \lambda^{2}}{g(k-\gamma v \lambda)}}
\end{array}\right\}
$$

これ等の $\mu$ の值を(3.8) 式に入れ， $C_{1}, C_{2}$ を任意常数とすれば

$$
w=C_{1} \exp \left(\lambda s+\mu_{1} z\right)+C_{2} \exp \left(\lambda s+\mu_{2} z\right)
$$

$z=0$ に於てはレールの撓み量と路盤の民カ力との間に次の関係が成立つ要がある。

$$
E J \frac{\partial^{4} w}{\partial s^{4}}+b_{0} p=0
$$

上式の $p$ に(3.5) 式を大れ, $w$ (3.11) 式を入れ小ば,

$$
C_{1}\left(E J \lambda^{4}-b_{0} k \mu_{1}+b_{0} \gamma v \lambda \mu_{1}\right)+C_{2}\left(E J \lambda^{4}-b_{0} k \mu_{2}+b_{0} \gamma \imath \lambda \mu_{2}\right)=0 \text {. }
$$

又 (3.11) 式に依る $w$ は $z=h$ に於て 0 となる要がある。このためには

$$
C_{1}=-C \exp \left(-\mu_{1} h\right), \quad C_{2}^{\prime}=C \exp \left(-\mu_{2} h\right)
$$

(3.14) 式を(3.13) 式に入れると $\lambda$ を求める式が得られる。

$$
E J_{\lambda^{4}}=-b_{0}(k-\gamma v \lambda)\left\{\psi+\frac{\sqrt{\psi^{2}+\frac{\rho v^{2} \lambda^{2}}{g(k-\gamma v \lambda)}}}{\tanh h \sqrt{\psi^{2}+\frac{\rho v^{2} \lambda^{2}}{g(k-\gamma v \lambda)}}}\right\}
$$

上式に於て特に $v=0$ とすれば

$$
E J \lambda^{4}=-\psi b_{0} k(1+\operatorname{coth} \psi h)
$$

これより弾性床の基礎係数 $K$ は $\psi b_{0} k(1+\operatorname{coth} \psi h)$ となることが判る。この時は荷重 $P(\mathrm{~kg})$ の下に於けるレー ル面の撓み量 $w_{s t}$ 及びレールに生ずる曲げモーメントは次式に依りあらおされる。

$$
w_{s t}=\frac{P}{8 E J_{\kappa^{3}}}, \quad M_{s t}=\frac{P}{4 \kappa}
$$

但し

$$
\kappa=\sqrt[4]{\frac{\psi b_{0} k(1+\operatorname{coth} \psi h)}{4 E J}}
$$

$v \neq 0$ の時は $\lambda$ の第 1 近似值を $(1 \pm i) \kappa$ 又は $(-1 \pm i) \kappa$ として，これ等を (3.15) 式の右辺に大れて漸次正確 な $\lambda$ の值が得られる。このよ なる。この $\lambda$ の值学 (3.10) 式の右辺に入れ入ば $\mu_{1}, \mu_{2}$ が求められるが

$$
\begin{aligned}
& \lambda=\alpha_{1} \pm i \beta_{1} \quad \text { に対し }\left\{\begin{array}{l}
\mu_{1}=-\psi+\frac{1}{h}\left(\sigma_{1} \pm i \tau_{1}\right) \\
\mu_{2}=-\psi-\frac{1}{h}\left(\sigma_{2} \pm i \tau_{1}\right)
\end{array}\right. \\
& \lambda=-\alpha_{2} \pm i \beta_{2} \text { に対し }\left\{\begin{array}{l}
\mu_{1}=-\psi+\frac{1}{h}\left(\sigma_{2} \mp i \tau_{2}\right) \\
\mu_{2}=-\psi-\frac{1}{h}\left(\sigma_{2} \mp i \tau_{2}\right)
\end{array}\right\}
\end{aligned}
$$

と書きめらわす。

$v \neq 0$ の時 (3.15) 式を满す $\lambda$ の根は上記の 4 個に限らず更に無限に多数ある。これ等の根を求めるには

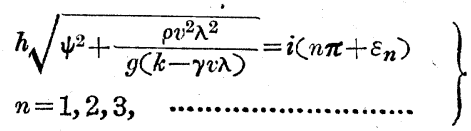

と置いて (3.15) 式を変形すれば

$$
\tan \varepsilon_{n}=\frac{b(\gamma v \lambda-k)\left(n \pi+\varepsilon_{n}\right)}{h\left\{E J \lambda^{4}-\psi b(\gamma \cdot \lambda-k)\right\}}
$$


となり， $\varepsilon_{n}$ の第 1 近似值を 0 と批いて (3.20) 式上り $\lambda$ の第 1 近似值を求め，次に $\varepsilon_{n}, \lambda$ の第 1 近似值を（3.

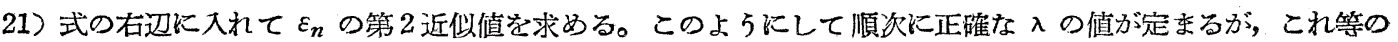

$\lambda$ は常に正の実数倍を持つ複菜数となるか，或いは正の奏数となる。これを $\alpha_{1 n} \pm i \beta_{1 n}$ (但し $n=1,2, \cdots \cdots . .$. とし (3.10) 式に依り

$$
\lambda=\alpha_{1 n} \pm i \beta_{1 n} \text { に対し }\left\{\begin{array}{l}
\mu_{1}=-\psi+\frac{1}{h}\left(\sigma_{1 n} \pm i \tau_{1 n}\right) \\
\mu_{2}=-\psi-\frac{1}{h}\left(\sigma_{1 n} \pm i \tau_{1 n}\right)
\end{array}\right\}
$$

とする。このよ5にして求めた多数の $\lambda, \mu_{1}, \mu_{2}$ を(3.11) 式炕入れると $w$ の一般解が求められるが，この中 で次の条件を満す解学選ぶこと小する。郎方

$s \leqq 0$ に於て $w=w_{1}$ とし, $s \rightarrow-\infty$ に於て $w_{1} \neq \infty$

$s \geqq 0$ に於て $w=w_{2}$ とし, $s \rightarrow \infty$ に於て $w_{2} \neq \infty$

とする。然る時性

$$
\begin{aligned}
w_{1}= & -\Sigma \exp \left(\alpha_{j s}-\psi z-\sigma_{j} \frac{h-z}{h}\right)\left\{A_{j} \cos \left(\beta_{j s}-\tau_{j} \frac{h-z}{h}\right)+B_{j} \sin \left(\beta_{j s}-\tau_{j} \frac{h-z}{h}\right)\right\} \\
& +\Sigma \exp \left(\boldsymbol{\alpha}_{j s}-\psi z+\sigma_{j} \frac{h-z}{h}\right)\left\{A_{j} \cos \left(\beta_{j s}+\tau_{j} \frac{h-z}{h}\right)+B_{j} \sin \left(\beta_{j s}+\tau_{j} \frac{h-z}{h}\right)\right\}
\end{aligned}
$$

但ᄂ $j=1,11,12,13$,

$$
\begin{aligned}
w_{2}= & -\exp \left(-\alpha_{2} s-\psi z-\sigma_{2} \frac{h-z}{h}\right)\left\{A_{2} \cos \left(\beta_{2} s+\tau_{2} \frac{h-z}{h}\right)+B_{2} \sin \left(\beta_{2} s+\tau_{2} \frac{h-z}{h}\right)\right\} \\
& +\exp \left(-\alpha_{2} s-\psi z+\sigma_{2} \frac{h-z}{h}\right)\left\{A_{2} \cos \left(\beta_{2} s-\tau_{2} \frac{h-z}{h}\right)+B_{2} \sin \left(\beta_{2} s-\tau_{2} \frac{h-z}{h}\right)\right\}
\end{aligned}
$$

上式の $A_{j}, B_{j}, A_{2}, B_{2}$ 活任意常数であるが次の境界条件飞依つて決定される。
(a) $s=0: w_{1}=w_{2}$
(b) $s=0: \frac{\partial w_{1}}{\partial s}=\frac{\partial w_{2}}{\partial s}$
(c) $s=0, \quad z=0: \frac{\partial^{2} w_{1}}{\partial s^{2}}=\frac{\partial^{2} w_{2}}{\partial s^{2}}$
(d) $s=0, \quad z=0: \frac{\partial^{3} w_{1}}{\partial s^{3}}+\frac{P}{E J}=\frac{\partial^{3} w_{2}}{\partial s^{3}}$

然しこの計算は一般に湛7煩雑なるむめ, 次に弾性体の慣性に依る影響と摩擦抵抗の影響とを別々に取出して 吟味すること〉する。

(i) 慣性に依る影響

$\gamma \rightarrow 0$ とすれば $\alpha_{1}=\alpha_{2}, \beta_{1}=\beta_{2}, \sigma_{1}=\sigma_{2}, \tau=\tau_{2}$ となり，乙れ等を $\alpha, \beta, \sigma, \tau$ と置く。又 $\alpha_{1 n}=0, \sigma_{12}=0$ (但し $n=1,2,3, \cdots . . .$.$) となる。これ等の関係を(3.23) 式に入れ，且(a)，(c) の条件を考慮すれ代 (3.23) 式の常数$ は次の関係を満す要がある。

$$
A_{1}=A_{2}(=A \text { 之置く, }) \quad-B_{1}=B_{2}(=B \text { と置く }) \quad B_{1 n}=0(n=1,2,3, \cdots \cdots)
$$

以上の諸式を用いて (3.23) 式を書き直せば

$$
\begin{aligned}
w_{1} & =-\exp \left(\alpha s-\psi z-\sigma \frac{h-z}{h}\right)\left\{A \cos \left(\beta s-\tau \frac{h-z}{h}\right)-B \sin \left(\beta s-\tau \frac{h-z}{h}\right)\right\} \\
& +\exp \left(\alpha s-\psi z+\sigma \frac{h-z}{h}\right)\left\{A \cos \left(\beta s+\tau \frac{h-z}{h}\right)-B \sin \left(\beta s+\tau \frac{h-z}{h}\right)\right\} \\
& -2 \sum_{n} A_{1 n} \exp (-\psi z) \sin \beta_{1 n} \sin \tau_{1 n} \frac{h-z}{h} \\
w_{2} & =-\exp \left(-\alpha s-\psi z-\sigma \frac{h-z}{h}\right)\left\{A \cos \left(\beta s+\tau \frac{h-z}{h}\right)+B \sin \left(\beta s+\tau \frac{h-z}{h}\right)\right\} \\
& +\exp \left(-\alpha s-\psi z+\sigma \frac{h-z}{h}\right)\left\{A \cos \left(\beta s-\tau \frac{h-z}{h}\right)+B \sin \left(\beta s-\tau \frac{h-z}{h}\right)\right\}
\end{aligned}
$$

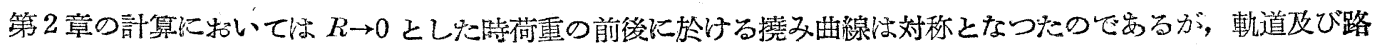
盤の質量が分右している時は (3.25) 式に示す如く一般汇荷重の前後に於ける撓み量は対称とはならない。为の 
最後の項は $s \rightarrow-\infty$ に特いても 0 とはならず, 荷重の後方の路盤に振動を残すことを示してい当。

(3.25) 式に依る $w_{1}, w_{2}$ を(b) の条件に入れ小ば次式が得られる。

$2(\alpha A-\beta B) \sinh \sigma \frac{h-z}{h} \cos \tau \frac{h-z}{h}-2(\beta A+\alpha B) \cosh \sigma \frac{h-z}{h} \sin \tau \frac{h-z}{h}$

$$
-\sum_{n} \beta_{1 n} A_{1 n} \sin \tau_{1 n} \frac{h-z}{h}=0
$$

上式に於て特に $z=0$ と固けば

$$
2(\alpha A-\beta B) \sinh \sigma \cos \tau-2(\beta A+\alpha B) \cosh \sigma \sin \tau-\sum_{n} \beta_{1} A_{1 n} \sin \tau_{1 n}=0
$$

然し (3.26) 式は $z=0$ †゙けに限らず $0 \leqq z \leqq h$ な範囲の総ての $z$ に対して成立する要が女る。

今 $\frac{h-z}{h}=\zeta$ とし, 更に

$\sinh \sigma \zeta \cos \tau \zeta=\phi_{1}(\zeta), \cosh \sigma \zeta \sin \tau \zeta=\varphi_{11}(\zeta), \sin \tau_{1 n} \zeta=\Phi_{n}(\zeta), n=1,2,3$,

と置けば (3.26) 式梳

$$
2(\alpha A-\beta B) \phi_{1}(\zeta)-2(\beta A+\alpha B) \phi_{11}(\zeta)-\sum_{n} \beta_{1 n} A_{1 n^{n}} \phi_{n}(\zeta)=0
$$

となる。上式が $0 \leqq \zeta \leqq 1$ なる範囲の総ての $\zeta$ に対して成立するためには次の関係を必要とする。

$$
\begin{aligned}
& 2(\alpha A-\beta B)(\mathrm{I}, \mathrm{I})-2(\beta A+\alpha B)(\mathrm{I}, \mathrm{II})-\sum_{n} \beta_{1 n} A_{1 n}(\mathrm{I}, n)=0 \\
& 2(\alpha A-\beta B)(\mathrm{I}, \mathrm{I})-2(\beta A+\alpha B)(\mathbb{I}, \text { II })-\sum_{n} \beta_{1 n} A_{1 n}(\mathbb{I}, n)=0 \\
& 2(\boldsymbol{\alpha} A-\beta B)(m, \mathrm{I})-2(\beta A+\alpha B)(m, \mathbb{I})-\sum_{n} \beta_{1 n} A_{1 n}(m, n)=0 \\
& \quad m=1,2,3, \ldots \ldots \ldots \ldots . .
\end{aligned}
$$

但ᄂ $\quad(i, j)=\int_{0}^{1} \Phi_{i}(\zeta) \phi_{j}(\zeta) d \zeta$

$$
i, j=\mathrm{I}, \mathrm{II}, 1,2,3 \text {, }
$$

$$
\}
$$

次に (d) の条件に(3.25) 式を入れて計算を進めれば次式を得る。

$4 \alpha \beta(\alpha A-\beta B) \cosh \sigma \sin \tau+4 \alpha \beta(\beta A+\alpha B) \sinh \sigma \cos \tau$

$$
-\sum_{n} \beta_{1 n} A_{1 n}\left(\beta_{1 n^{2}}+\alpha^{2}-\beta^{2}\right) \sin \tau_{1 n}=\frac{P}{2 E J}
$$

結局 (3.27)，(3.30)，(3.32) 式上り $A, B, A_{11}, A_{12}, \cdots \cdots \cdots$ 等の未知数が決定される。

これ等の值を(3.25) 式に入れると走行荷重に從つて軌道及び路盤に生ずる運動をあらわす方が得られる。特

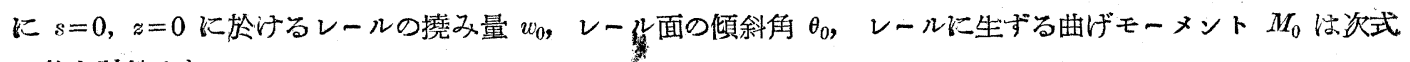
に依り計算される。

$$
\left.\begin{array}{l}
w_{0}=2(A \sinh \sigma \cos \tau-B \cosh \sigma \sin \tau) \\
\tan \theta_{0}=\sum_{n} A_{1 n} \beta_{1 n} \sin \tau_{1 n} \\
M_{0}=2 E J\left\{\left(\beta^{2}-\alpha^{2}\right)(A \sinh \sigma \cos \tau-B \cosh \sigma \sin \tau)+2 \alpha \beta(A \cosh \sigma \sin \tau+B \sinh \sigma \cos \tau)\right.
\end{array}\right\}
$$

上式より見られるよ5に一般比 $s=0$ に於けるレール面の傾斜湖は 0 とはならず, 從つてレールの最大撓みを 生ずる位置は荷重の少し後方にある。この最大撓み学 $w_{\mathrm{m} \text { ax }}$ とすればこの概略の大きさは次式に依つて計算され る。

$$
w_{\max }=w_{0}+\frac{E J \tan ^{2} \theta_{0}}{2 M_{0}}
$$

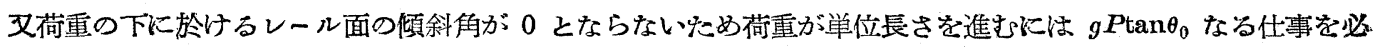
要とする。この仕事は荷重の後方の軌道に変形更び運動のエネルギーとして残される算である。從つて

$$
g P \tan \theta_{0}=\lim _{s \rightarrow-\infty}\left\{\int_{0}^{h} \frac{1}{2} b g k\left(\frac{\partial w}{\partial z}\right)^{2} d z+\int_{0}^{h} \frac{1}{2} b \rho v^{2}\left(\frac{\partial w}{\partial s}\right)^{2} d z\right\}
$$

(3.25) 及び (3.33) 式を用いて上式を計算すれば

$$
P \sum_{n} A_{1 n} \beta_{1 n} \sin \tau_{1 n}=\frac{b_{0} k}{h} \sum_{n} A_{1 n^{2}}\left\{\tau_{1 n^{2}}+\frac{\psi h}{2}\left(\cos 2 \tau_{1 n}\right)+\psi^{2} h^{2}\left(1-\frac{\sin 2 \tau_{1 n}}{2 \tau_{1 n}}\right)\right\}
$$

上式は $A, B, A_{11}, A_{12} \cdots \cdots \cdots$ 等を計算する時前述の諸式に併用し得る。 $v$ が特に大さくならない限り一般に $A_{12} \fallingdotseq 0, A_{13} \fallingdotseq 0, \cdots \cdots$, 旦 $\tau_{11} \fallingdotseq \pi$ と見做されるから, (3.36) 式より $A_{11}$ を直接に求める式が得られる。 $A_{11} \fallingdotseq \frac{-P h \beta_{11} \varepsilon_{1}}{b_{0} k\left(\pi^{2}+\psi^{2} h^{2}\right)}$ 
上式に依つて $A_{11}$ が決末れば $A, B$ は (3.27) 区び (3.32) 式に依つて簡単に計算し得る。

(3.25) 式の $w_{1}$ の右辺の最後の項は走行荷重の後方に残される振動を示すのであるが第 $n$ 次振動の振幅は.

$$
a_{n}=2 A_{1 n} \exp (-\psi z) \sin \tau_{1 n} \frac{h-z}{h}
$$

に体つてせらわされる。 $\tau_{1 n}$ が $n \pi$ に近い数であることに注意すれば（3.38）式は或る深さで振幅が最大になる ことを示している。この振動のレールオ向に於ける波長 $S_{n}$, 深さのう向に於ける波長 $Z_{n}$ 及び振動数 $f_{n}$ は次 式に依つて計算される。

$$
S_{n}=\frac{2 \pi}{\beta_{1 n}}, Z_{n}=\frac{2 \pi h}{\tau_{1 n}}, f_{n}=\frac{\beta_{1 n^{v}}}{2 \pi}
$$

(ii) 摩擦抵抗力の影響.

慣性の影響を無視して摩擦抵抗力の影響のみを考慮した場合について計算を進めること〉する。このせめに は (3.6) 式に於て $\rho=0$ と置けばよい。然る時は

$$
p=p_{0} \exp (-2 \psi z)
$$

但し $p_{0}$ は $z=0$ に置ける圧力とする。上式を (3.5) 式に入れ， $z=h$ に於て $w=0$ となることを考慮すれば

$$
p_{0}\{\exp (-2 \psi z)-\exp (-2 \psi h)\}=2 \psi\left(k w-\gamma v \frac{\partial w}{\partial s}\right)
$$

上式の $z$ を と置いた時の $p_{0}$ を(3.12) 式の $p$ に入れれば

$$
E J \frac{\partial^{4} w}{\partial s^{4}}+\psi b_{0}(1+\operatorname{coth} \psi h)\left(k w-\gamma v \frac{\partial w}{\partial s}\right)=0
$$

この式は (2.2) 式に於て $y$ を を $w$ とし,

$$
m=0, \quad K=\psi b_{0} k(1+\operatorname{coth} \psi h), \quad R=\frac{K \gamma}{k}
$$

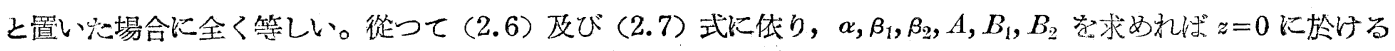
レールの撓み曲線が得られる。又 (3.41) 式に依り $w$ と $z$ と関倸が得られるのでこ机等学㴊世考慮して次式 が得られる。

$$
\left.\begin{array}{l}
w_{1}=\frac{\exp (-2 \psi z)-\exp (-2 \psi h)}{1-\exp (-2 \psi h)} \exp (\alpha s)\left(A \cos \beta_{1} s+B_{1} \sin \beta_{1} s\right) \\
w_{2}=\frac{\exp (-2 \psi z)-\exp (-2 \psi h)}{1-\exp (-2 \psi h)} \exp (-\alpha s)\left(A \cos \beta_{2} s+B_{2} \sin \beta_{2} s\right)
\end{array}\right\}
$$

以上の計算に依れば路盤の質量を無視した場合に限り, 路盤内の変形の速度に比例する摩擦抵抗力が作用する としても, ヌレールの攃み運動の速度に比例する摩擦抵抗力が作用するとしてもとの結果伍同一となつた。

\section{4. 実験値と計算值との比較}

\section{（i）軌道材料欧び路盤の翼性の影響}

東海道線三島沿津間飞於て図-4.1 亿示与編成の電車 の試運転を行つた時にレール又は枕木の撓み量学測定し 且路船に生ずる振動穵測定した。撓み量測定に心撓度計 を用いて撓夕量を 3 5 倍に拡大乙て記録し, 路盤の振 動測定には石本式振動計を秋木間の道床面に据付けを。 この振動計の固有周期は 0.08 秒でせる。レール重量 $50 \mathrm{~kg} / \mathrm{m}$, 枕木間隔 $67 \mathrm{~cm}$, 砾石道床, 築堤の高さ約 $4 \mathrm{~m}$ であつけ。

図-4.1

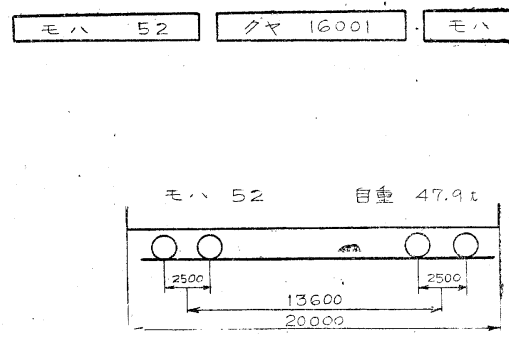

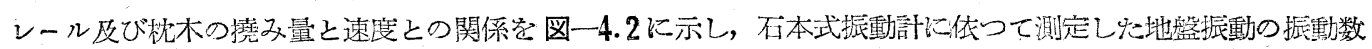

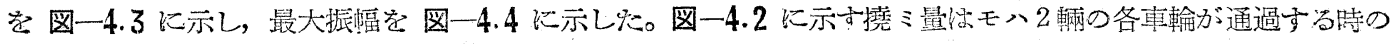

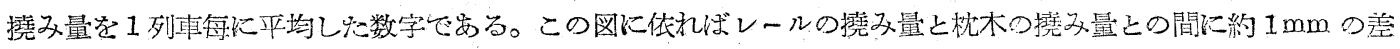

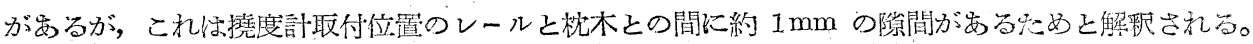

今レール交承体沈下係数学 $\mathrm{D}=24,000 \mathrm{~kg} / \mathrm{cm}$ としてモ゙のの备車輪（輪重 $6,000 \mathrm{~kg}$ ）に传つて生ずるレール の葑み量を計算すれば $w_{s t}=0.1045 \mathrm{~cm}$ となり，これに隣接の車輪の影響を加えれば $0.100 \mathrm{~cm}$ となる。この值

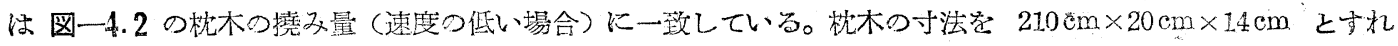




\section{図-4.2}
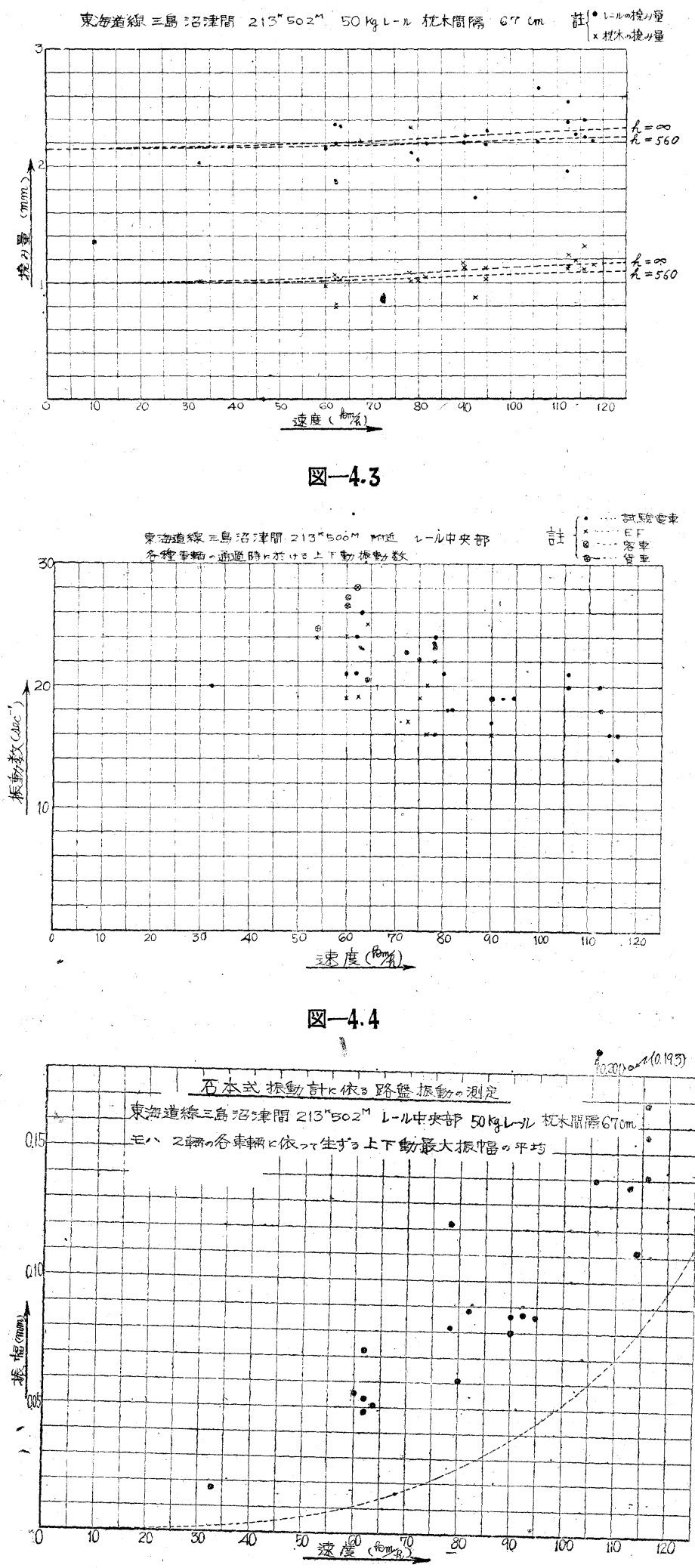
ば $D=24,000 \mathrm{~kg} / \mathrm{cm}$ に対して道床係数は $C=13 \mathrm{~kg} / \mathrm{cm}^{3}$ となる。ブーシネスクの弾性論を用いれば底面栍が $210 \mathrm{~cm} \times 20 \mathrm{~cm}$ の枕木で測定した道床係数と地盤のヤング係数 $E^{\prime}\left(\mathrm{kg} / \mathrm{cm}^{2}\right)$ との間には次の関係が導かれる。

$$
C=\frac{E^{\prime}}{45.7\left(1-\sigma^{2}\right)} \text {. }
$$

上式に於ける $\sigma$ はポアソン比である。今 $\sigma=0.3$ として上式より $E^{\prime}$ を求めれば $E^{\prime}=540 \mathrm{~kg} / \mathrm{cm}^{2}$ となる。 又 (3.2) 式に作つて圧縮に対する弾性係数を求めれば $k=727 \mathrm{~kg} / \mathrm{cm}^{2}$ となる。道床及び路盤の泌度を平均して 1.7 とすれば $\rho=0.0017$ となる。

(3.1) 式に於ける $b_{0}$ を $120 \mathrm{~cm}$ とし， $\psi$ を $0.002 \mathrm{~cm}^{-1}$ とし， $h=560 \mathrm{~m}$ とすれば，K= $\psi b_{0} k(1+\operatorname{coth} \psi h)=$ $390 \mathrm{~kg} / \mathrm{cm}^{2}$ となる。(3.18)式より $\kappa=0.01278$, 荷重の速度を $100 \mathrm{~km} / \mathrm{h}$ とすれば $v=2780 \mathrm{~cm} / \mathrm{sec}$ となる。 $\gamma=0$ と して (3.15) 式より $\lambda=\alpha \pm i \beta$ を求めれば $\alpha=0.01213, \beta=0.01357$ となり, (3.10)式に传つて $\mu=-\psi+\frac{1}{h} C$ $\left.\sigma_{ \pm} i \tau\right)$ を求めれば $\sigma=1.267, \tau=0.751$ を得る。(3.20)，(.21) 式に依り $\varepsilon_{1}=-0.0366, \alpha_{11}=0, \beta_{11}=0.0434$, $\sigma_{11}=0, \tau_{11}=3.1050,(3.37)$ 式に依り $A_{11}=0.0571 w_{s t}$, (3.27) 改び (3.32) 式に依り $\alpha A-\beta B=0.00541 w_{s t}$, $\boldsymbol{\beta} A+\boldsymbol{\alpha} B=0.00491 w_{s t}$, 從つて $A=0.399 w_{s t}, \quad B=-0.0417 w_{s t}, \quad$ (3.33) 式に依れば $w_{0}=1.06 w_{s t}, \quad \tan \theta_{0}=$ $0.00711 \kappa w_{s t}{ }^{* 4}, M_{0}=1.071 M_{s t}$ を得る。又 (3.34) 式に佉つて計算すれば $w_{\mathrm{m} \text { ax }}$ ほ $w_{0}$ と差がない。以上の計 算に依れば速度 $100 \mathrm{~km} / \mathrm{h}$ の動荷重に依るレールの撓み量及び曲げモーメントは静荷重の場合の 6〜7\% 增しと なり，第 2 章に依る計算に較べて甚で大さい。(3.38) 式に依り $z=100 \mathrm{~cm}$ として第 1 次振動の振幅を計算すれ. ば $a_{1}=0.0521 w_{s t}$ となり, 又 (3.39) 式に体れば振動数は $f_{1}=19.2$ となる。

同様にしてこの他の速度についてるレールの撓み量, 傾斜角, 曲げモーメント, 路盤の振動振幅, 振動数を計 算すれば 表一2 の如くなる。

$w_{s t}$ は略 $1 \mathrm{~mm}$ であり, 隣接荷重の影響は非常に 小さいので表一2の撓み量及び振幅は mm の単位 で示されていると見てよい。上表の撓み量及び振幅

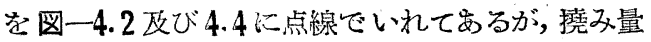
は実験結果民較べて幾分小さい。又計算より得タ振 幅は測定值に較べて非常に少いが，測定值は最大振 幅を採つをたさ差を生じたものと解される。表一2 に依れば路盤の振動数は略 $19 \mathrm{sec}^{-1}$ となり, 速度の

\begin{tabular}{c|c|c|c|c|c}
\multicolumn{7}{c}{ 表一 2} \\
\hline 速 度 & $\mathrm{km} / \mathrm{h}$ & 0 & 60 & 100 & \multicolumn{1}{|c}{120} \\
\hline$w_{0}$ & $w_{s t}$ & 1 & 1.019 & 1.062 & 1.083 \\
$\tan \theta_{0}$ & $\kappa w_{s t}$ & 0 & 0.0003 & 0.0071 & 0.0218 \\
$M_{0}$ & $M_{s t}$ & 1 & 1.021 & 1.071 & 1.094 \\
$a_{1}$ & $w_{s t}$ & 0 & 0.0107 & 0.0521 & 0.0957 \\
$f_{1}$ & $\mathrm{sec}^{-1}$ & & 19.4 & 19.2 & 19.0
\end{tabular}
增加に依つて僅かに減少寸る。これは実験結果によく一致している。

(ii) 路盤の変形に対する内部摩摖の影響

第 3 章で䜽じたよ 5 に路盤の内部に変形の速度に比例する摩擦抵抗力がある眭は荷重の前方に於けるレールの 撓み曲線と後方に於けるものとは異る。レールの撓み量測定記録に体ればこの影響が明かに認められる場合も㐫 り又全然認められない場合もある。

その1例として東北線白河に於て測定した撓度諳記録から荷重の前後に於けるレール面の最急勾配を測り, こ れを図一 4.5 に示す。(2.11)及び(3.43) 式に依り $f$ は $2 \gamma$ に比例するから 図一2.2 に依り速度が大きくなる 図-4-5

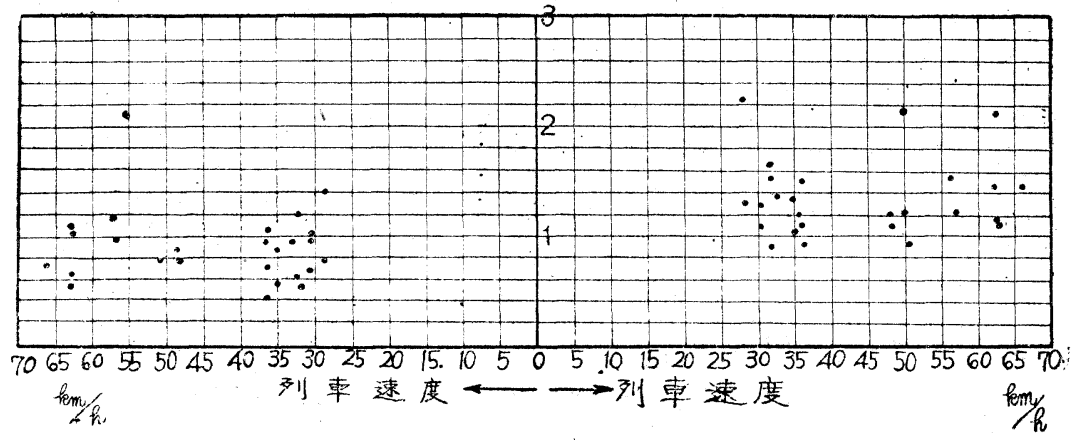


程荷重の前後に於ける撓み曲線の勾配の差が大きくなる等であるが，図-4.5 は速度に传つて㱠ど変化のないこ

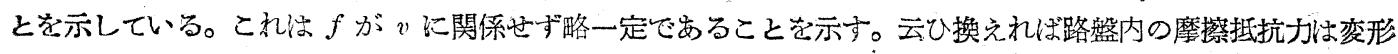
の速度に関係せず略一定である。

この図に依れば荷重の前方に於ける勾配は 1.2 となり，後方では 0.8 となり，その比は 0.5 である。図一

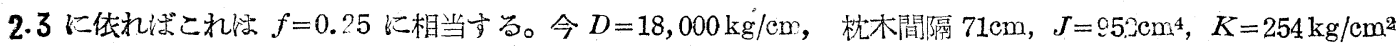
とすれば $k=545 \mathrm{~kg} / \mathrm{cm}^{2}, \kappa=0.0133 \mathrm{~cm}^{-1}$ となる。(2.11) 及び (3.43) 式に依り計算すれば， $\gamma v=20,500 \mathrm{~kg} / \mathrm{cm}$ を得る。

今 $P=7500 \mathrm{~kg}, b_{0}=120 \mathrm{~cm}$ として (3.3) 式右边第2 項の最大值を計算すれば $\left|\gamma \frac{\partial^{2} w}{\partial z \partial t}\right|_{\mathrm{m} \text { ax }}=0.13 \mathrm{~kg} / \mathrm{cm}^{2}$ と なり，又第1 項の最大值保 $\left|k \frac{\partial w}{\partial z}\right|_{\max }=0.42 \mathrm{~kg} / \mathrm{cm}^{2}$ となる。剆ち内部摩擦に依る最大抵抗力が弾性に依る最大 抵抗力の $31 \%$ となる。これは摩擦抵抗力が特に大きくあらわれた例で㐫り，一般には非常に小さく，認められ ない場合も多い。

\section{5. 深さ無限の彈性築堤上にある長さ無限の梁}

・本章では路盤の深さを無限として軌道及び路盤の撓み運動穵袷ずること〉する。軌道上部の圧力を受ける路盤 の幅は (3.1) 式に示す上らに梁さの増寸に從い広く採る。このよ5にすれば $h \rightarrow \infty$ として (3.1) から (3. 13) 式まではそのま入適用出来る。

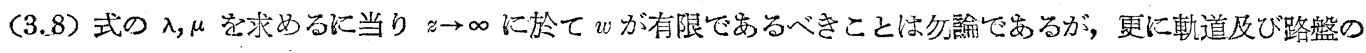

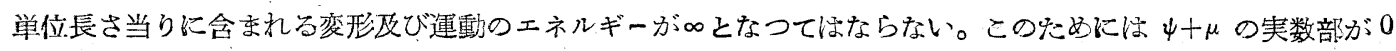

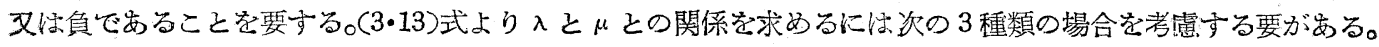

(甲) : $\left.\quad C_{1} \neq 0, \quad C_{2}=0, \quad E J_{\lambda^{4}-b_{0} k \mu_{1}+b_{0} \gamma v \lambda \mu_{1}=0}\right\}$

(乙) : $\left.\quad C_{1}=0, \quad C_{2} \neq 0, \quad E J \lambda^{4}-b_{0} k \mu_{2}+b_{0} \gamma 2 \lambda \mu_{2}=0 \quad\right\}$

(两) : $C_{1} \neq 0, \quad C_{2} \neq 0$

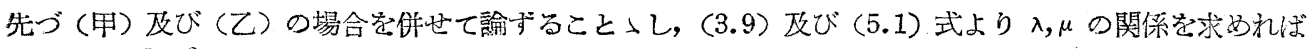
$\mu=\frac{b_{0} \rho v^{2}}{E J g \lambda^{2}}-2 \psi$

この $\mu$ の式を(5.1) 式炕入ると

$$
E J \lambda^{4}=\dot{b_{0}}\left(\frac{b_{0} \rho v^{2}}{E J g \lambda^{2}}-2 \psi\right)(k-\gamma \nu \lambda)
$$

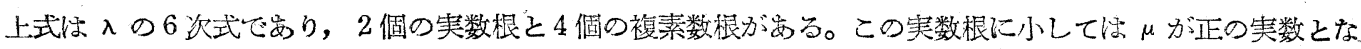
り, $z \rightarrow \infty$ に於て $w \rightarrow \infty$ となつて不適当である。

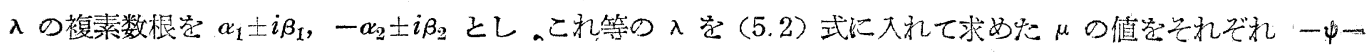
$\sigma_{1} \mp i \tau_{1}, \quad-\psi-\sigma_{2} \pm i \tau_{2}$ とする。 $\sigma_{1}, \sigma_{2}$ は正となるので $\psi+\mu$ の害数部は負となる。これ等の $\lambda, \mu$ の值を (3.8) に大れ入ばwの一般解が求められるがこの中で次の条件を満す解を求める。郎ち

$s \leqq 0$ に於て $w=w_{1}$ とし, $s \rightarrow-\infty$ に於て $w_{1} \neq \infty$,

$s \geqq 0$ に於て $w=w_{2}$ とし, $s \rightarrow \infty$ に於て $w_{2} \mp \infty$

然る時惊

$$
\left.\begin{array}{l}
w_{1}=\exp \left(\alpha_{1} s-\psi z-\sigma_{1} z\right)\left\{A_{1} \cos \left(\beta_{1} s-\tau_{1} z\right)+B_{1} \sin \left(\beta_{1} s-\tau_{1} z\right)\right\} \\
w_{2}=\exp \left(-\alpha_{2} s-\psi z-\sigma_{2} z\right)\left\{A_{2} \cos \left(\beta_{2} s+\tau_{2} z\right)+B_{2} \sin \left(\beta_{2} s+\tau_{2} z\right)\right\}
\end{array}\right\}
$$

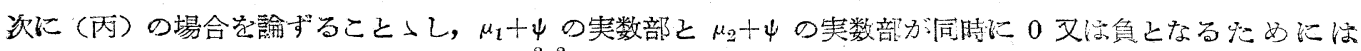

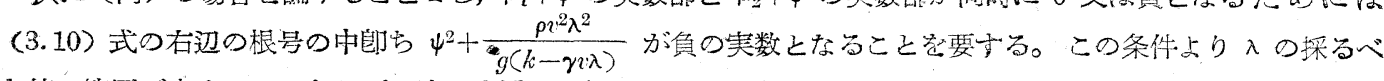
き㖊の範国が定委るのであるが，次の 2 通りの場合に分けて諭ずるのが便利である。

(两1) $g \gamma^{2} \psi^{2}<4 k \rho$

(丙2) $g \gamma^{2} \psi^{2}>4 k \rho$

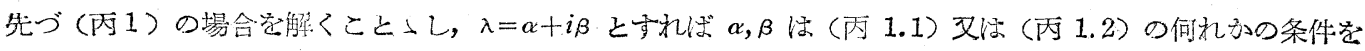
满さねばならない。

(丙 1.1) $\dot{\alpha>\frac{k}{\gamma v}}, \quad \cdot \beta=0$

(丙 1.2) $\frac{g \gamma \psi^{2}}{2 \rho v}<\alpha<\frac{2 k}{\gamma v}, \beta^{2}=\alpha\left(\frac{2 k}{\gamma v}-\alpha\right)$ 
(丙 2 ) の場合にも $\lambda=\alpha+i \beta$ と置けば $\beta=0$ となり， $\alpha$ は或る特定の範囲内にある正の実数となる。 以上の各程の場合に対し

$$
\frac{\rho v^{2} \lambda^{2}}{g(\gamma v \lambda-k)}-\psi^{2}=w^{2}
$$

之置けば $w$ 快実数となり， $\mu_{1}, \mu_{2}$ は

$$
\mu_{1}=-\psi+i w, \quad \mu_{2}=-\psi-i w
$$

を以てあらわされる。

以上の条件学満军 $\lambda, \mu$ の值を (3.13) 式に入れて $C_{1}, C_{2}$ の值を決めれば

$C_{1}=-Q(\alpha+i \beta)^{2}\left(w^{2}+\psi^{2}\right)+\psi+i w$

$C_{2}=Q(\boldsymbol{\alpha}+i \beta)^{2}\left(w^{2}+\psi^{2}\right)-\psi+i w$

但ᄂ $Q=\frac{E J g}{b_{0} \rho q^{2}}$

$$
\}
$$

この $C_{1}, C_{2}$ を(3.11) 式に入れ入ば次の 2 種類の解が得られる。

$$
\begin{aligned}
w_{11} & =\exp (\alpha s-\psi z)\left[\left\{Q\left(\beta^{2}-\alpha^{2}\right)\left(w^{2}+\psi^{2}\right)+\psi\right\} \sin \beta \sin w z\right. \\
& \left.-2 Q \alpha \beta\left(w^{2}+\psi^{2}\right) \cos \beta s \sin w z+w \sin \beta s \cos w z\right] \\
w_{12} & =\exp (\alpha s-\psi z)\left[\left\{Q\left(\beta^{2}-\alpha^{2}\right)\left(w^{2}+\psi^{2}\right)+\psi\right\} \cos \beta s \sin w z\right. \\
& \left.+2 Q \alpha \beta\left(w^{2}+\psi^{2}\right) \sin \beta s \sin w z+w \cos \beta s \cos w z\right]
\end{aligned}
$$

（丙 1.2）の場合には上の 2 種類の解が共に存在するが（丙 1.1）又は（丙2）の場合には $\beta=0$ となるのた $w_{11}$ は存在しない。何れの場合にも $\alpha$ は常に正の実数となるので $w_{11}, w_{12}$ は共に $s \leqq 0$ の籍囲のみ络適され る。又上式に於ける $\beta, w$ は $\alpha$ に依つて定まるが $\alpha$ は指定の範囲内で任意に選び得るので上式に $\alpha$ の任意の

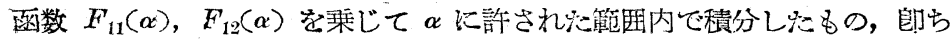

$$
\int F_{11}(\boldsymbol{\alpha}) w_{11} d \boldsymbol{\alpha}+\int F_{12}(\boldsymbol{\alpha}) w_{12} d \boldsymbol{\alpha}
$$

す亦解となる。この式を (5.4) 式に体る $w_{1}$ の右辺に加えれば $w_{1}$ の最も一般的な解が得られる。

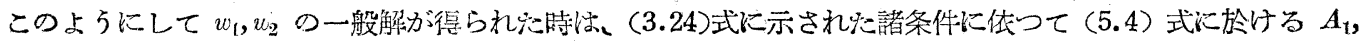

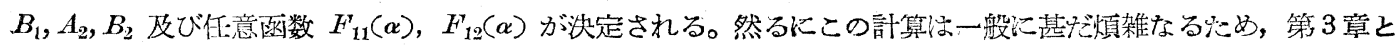
同様に弾性体の䀧性红依る影響と摩擦抵抗の影響とを別々に取出して哈味することつする。

(i ) 慻性に低る影響

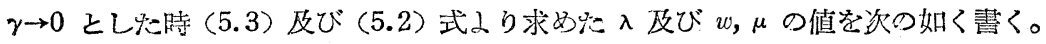

$$
\lambda= \pm\left(\alpha_{0}+i \beta_{0}\right) \text { に対し } \mu=-\psi-\sigma-i \tau \quad \lambda= \pm\left(\alpha_{0}-i \beta_{0}\right) \text { に対し } \mu=-\psi-\sigma+i \tau
$$

これ等の値を (5.4) 式に入れると (甲) 改び (乙) の場合の解が得られる。

次に (丙) の場合の解穵求めるのであるが， $\alpha \rightarrow \infty$ となつて適当でない。(丙 1.2）の場合には $\alpha$ は任意の正の奏数として差支光ないが， $\alpha$ の大きさを有 限とすれば $\beta \rightarrow \infty$ となつて適当でない。逆に $\beta$ を有限の大きさとすれば $\alpha=0$ となり，この場合でけが丙の解 として使われる。

(5.7) 式に於て $\gamma \rightarrow 0, \alpha \rightarrow 0$ と置けば

$$
\beta=\nu \sqrt{u^{2}+\psi^{2}} \text {, 但し } \nu=\sqrt{\frac{g k}{\rho v^{2}}}
$$

(5.10) 式の $\alpha, \beta$ に上記の值を入れ $\Phi(w), \Psi(w)$ 学秉じてwで積分した式も亦解となる。この式を (5.4) 式の $w_{1}$ の右辺に加えれば $w_{1}, w_{2}$ の一般 解として次式が得られる。

$$
\begin{aligned}
& w_{1}=\exp \left(\alpha_{0} s-\psi z-\sigma z\right)\left\{A_{1} \cos \left(\beta_{0} s-\tau z\right)+B_{1} \sin \left(\beta_{0} s-\tau z\right)\right\} \\
& +\exp (-\psi z) \int_{0}^{\infty}\left\{\Phi(w) \sin \sqrt{w^{2}+\psi^{2}} \nu s+\Psi(w) \cos \sqrt{u^{2}+\psi^{2}} \nu s\right\} \\
& \quad \times\left[\left\{V\left(u^{2}+\psi^{2}\right)^{2}+\psi\right\} \sin u z+w \cos u z\right] d w \\
& w_{2}=\exp \left(-\alpha_{0} s-\psi z-\sigma z\right)\left\{A_{2} \cos \left(\beta_{0} s+\tau z\right)+B_{2} \sin \left(\beta_{0} s+\tau z\right)\right\} \\
& \text {,但し } \quad V=\frac{E J}{b_{0} k}\left(\frac{g k}{\rho v^{2}}\right)^{2}
\end{aligned}
$$

上式に答ける $A_{1}, B_{1}, A_{2}, B_{2}, \Phi(w) ， \Psi(w)$ は(3.24) 式に示した諸条件飞值り決定される。 
先づ (a) 及び (c) の条件を満足するためには

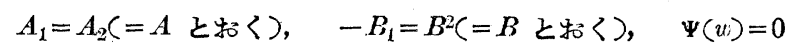

となる要がある。又計算の便宜上

$$
\Phi(w)=\frac{2 F(w)}{\nu u \sqrt{w^{2}+\psi^{2}}}
$$

乙置けば (5.17) 式は

$$
\left.\begin{array}{rl}
w_{1} & =\exp \left(\alpha_{0} s-\psi z-\sigma z\right)\left\{A \cos \left(\beta_{0} s-\tau z\right)-B \sin \left(\beta_{0} s-\tau z\right)\right\} \\
& +2 \exp (-\psi z) \int_{0}^{\infty} \frac{F(w)}{\nu \sqrt{w^{2}+\psi^{2}}} \sin \sqrt{u^{2}+\psi^{2}} \nu s\left\{\frac{V\left(u^{2}+\psi^{2}\right)^{2}+\psi}{w} \sin u z+\cos u z\right\} d w \\
w_{2} & =\exp \left(-\alpha_{0} s-\psi z-\sigma z\right)\left\{A \cos \left(\beta_{0} s+\tau z\right)+B \sin \left(\beta_{0} s+\tau z\right)\right\}
\end{array}\right\}
$$

上式の $w_{1}, w_{2}$ 素(b) の条件に入れると次式が導かれる。

$\exp (-\sigma z)\left\{\left(\alpha_{0} A-\beta_{0} B\right) \cos \tau z+\left(\beta_{0} A+\alpha_{0} B\right) \sin \tau z\right\}$

$+\int_{0}^{\infty} F(u)\left\{\frac{V\left(u^{2}+\psi^{2}\right)^{2}+\psi}{w} \sin w z+\cos u z\right\} d u=0$

上式に於て $z=0$ と置けば次式が得られる。

$$
\boldsymbol{\alpha}_{0} A-\beta_{0} B+\int_{0}^{\infty} F(w) d w=0
$$

然し (5.15) 式は $z=0$ に限らず， $z \geqq 0$ なるすべての $z$ に対して成立するように $A, B, F(w)$ を決める要が あ。今

$$
\left.\begin{array}{l}
\exp (-\sigma z) \cos \tau z=f_{\mathrm{I}}(z), \exp (-\sigma z) \sin \sigma z=f_{\mathrm{II}}(z), \\
\frac{V\left(w^{2}+\psi^{2}\right)^{2}+\psi}{w} \sin w z+\cos w z=f_{w}(z)
\end{array}\right\}
$$

乙置けば (5.15) 式は

$$
\left(\alpha_{0} A-\beta_{0} B\right) f_{\mathrm{I}}(z)+\left(\beta_{0} A+\alpha_{0} B\right) f_{\mathrm{I}}(z)+\int_{0}^{\infty} F(w) f_{w}(z) d w=0
$$

となる。上式が $0 \leqq z の$ の箸囲で常に成立寸るためには次の諸式が満足されねばならない。

$$
\begin{aligned}
& \left(\alpha_{0} A-\beta_{0} B\right)(\mathrm{I}, \mathrm{I})+\left(\beta_{0} A+\alpha_{0} B\right)(\mathrm{I}, \mathbb{I})+\int_{0}^{\infty} F^{\prime}(w)(\mathrm{I}, w) d w=0 \\
& \left.\left(\alpha_{0} A-\beta_{0} B\right)(\mathbb{I}, \mathrm{I})+\left(\beta_{0} A+\alpha_{0} B\right)(\mathbb{I}, \mathbb{I})+\int_{0}^{\infty} F^{\prime} w\right)(\mathbb{I}, w) d w=0 \\
& \left(\alpha_{0} A-\beta_{0} B\right)(\mathrm{I}, \xi)+\left(\beta_{0} A+\alpha_{0} B\right)(\mathbb{I}, \xi)+\int_{0}^{\infty} f_{\xi}(z) \int_{0}^{\infty} F^{\prime}(w) f w(z) d w d z=0 \\
& \text { 但L }(i, j)=\int_{0}^{\infty} f_{i}(z) f_{j}(z) d z \quad i, j=\mathrm{I}, \mathbb{I}, w
\end{aligned}
$$

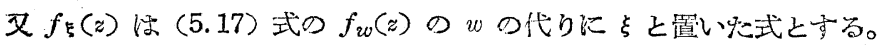

(3.24) 式の (d) の条件比 (5.14) 式を大れ小炏式が得られる,

$$
\frac{\alpha_{0} A-\beta_{0} B}{4 \sigma V}+2 \sigma \tau\left(\beta_{0} A+\alpha_{0} B\right)+\int_{0}^{\infty} F(w)\left(w^{2}+\psi^{2}\right) d w=\frac{P}{2 E J_{\nu^{2}}}
$$

結局 $A, B, F(w)$ を求める式として (5.16)，(5.19)，(5.20) 式があるが，乙れ等の式を変形すれば次式が導 加る。

$$
\begin{aligned}
& \frac{\tau}{\sigma}\left(\alpha_{0} A-\beta_{0} B\right)+\left\{g \sigma\left(\sigma^{2}+\tau^{2}\right) V-1\right\}\left(\beta_{0} A+\alpha_{0} B\right)=\frac{\sigma^{2}+\tau^{2}}{\tau} \cdot \frac{2 g P}{b_{0} \rho v^{2}} \\
& \left\{8 \sigma\left(\sigma^{2}+\tau^{2}\right) V-1\right\}\left(\alpha_{0} A-\beta_{0} B\right)-\frac{\tau}{\sigma}\left(\beta_{0} A+\alpha_{0} B\right)=0 \\
& F^{\prime}(w)=-\frac{P}{E J \nu^{2}} \cdot \frac{V w^{2}}{\pi\left[w^{2}+\left\{V\left(w^{2}+\psi^{2}\right)^{2}+\alpha\right\}^{2}\right]}
\end{aligned}
$$

(5.21) 式上り求めた $A, B$ 及び (5.22) 式に依る $F(w)$ を (5.14) 式に入れると $w_{1}, w_{2}$ が決定される。特化 シール面の接み曲線学得るため $z=0$ と置き，旦 $\sqrt{w^{2}+\psi^{2}}=\gamma$ と置けば

$$
\left.\begin{array}{l}
w_{1}=\exp \left(\alpha_{0} s\right)\left(A \cos \beta_{0} s-B \sin \beta_{0} s\right)-\frac{2 \nu P}{\pi b_{0} k} \int_{\psi}^{\infty} \frac{\sqrt{\gamma^{2}-\psi^{2}} \sin \gamma \nu s}{\gamma^{2}\left(V^{2} \gamma^{6}+2 \psi V \gamma^{2}+1\right)} d \gamma \\
w_{2}=\exp \left(-\alpha_{0} s\right)\left(A \cos \beta_{0} s+B \sin \beta_{0} s\right)
\end{array}\right\}
$$


(5.14) 又仙 (5.23) 式上り見られるよ5に走行荷重の後方の軌道及び路盤の撓み運動飞は振動の項が含皂れ て特り, 振動の土ネルギーは $s \rightarrow \infty$ に於ても0 とならない。この振動には一定の振動数はないが，振動数の最 小は $\frac{\psi}{2 \pi} \sqrt{\frac{g k}{\rho}}$ でこれよりのに至るまでの種々の振動数が念委机ている。

(5.23) 式に依れば $s=0, z=0$ に於けるレールの撓多量 $u_{0}$, レール面の傾斜陆 $\theta_{0}$, :レールに生ずる曲げモー メント $M_{0}$ 织次式に依つてあらわされる。

$$
\begin{aligned}
& w_{0}=A \\
& \tan \theta_{0}=\alpha_{0} A-\beta_{0} B \\
& \left.M_{0}=E J\left\{\beta_{0}{ }^{2}-\alpha_{0}{ }^{2}\right) A+2 \alpha_{0} \beta_{0} B\right\}
\end{aligned}
$$

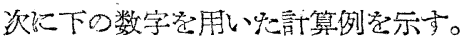

道床係数觉 $C=13 \mathrm{~kg} / \mathrm{cm}^{3}$ とすれ隹 $D=24,000 \mathrm{~kg} / \mathrm{cm} ， k=727 \mathrm{~kg} / \mathrm{cm}^{2}$ となる。 $b_{0}=120 \mathrm{~cm} ， \psi=0.002 \mathrm{~cm}^{-1}$

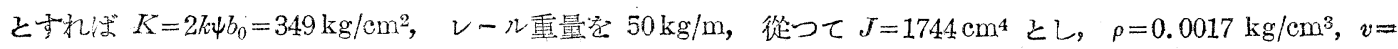

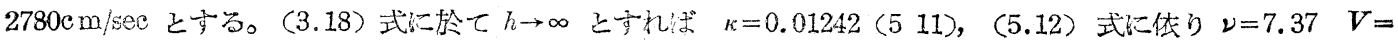
$123.4 \times 10^{6} \mathrm{~cm}^{3}$, (5.2) 不び (5.3) 式に体り $\alpha_{0}=0.01172, \beta_{0}=0.01367, \sigma=0.002,207, \tau=0.001,336,(5.21$ ) 式に依り $\alpha_{0} A-\beta_{0} B=0.00115 w_{s t}, \beta_{0} A+\alpha_{0} B=0.02566 w_{s t}$ ，乙れより $A=1.124 w_{s t}, B=0.879 w_{s t}$ 学得る。 (5. 24）式に依り荷重下に於けるレールの撓み量，レール面つ傾斜角，レールに生ずる曲げモーメントを計算すれ ば表一了の如くなる。

同稼なオ法で各種の速度に郝して計算しな結果も併せて 表一了に示す。

表一3 表一2 に比較すればレール 撓み量の壇 加率が約2 倍になり。曲げモーメントの增加率社高 速度に於て略一致する。表一ろに依れば荷重下のレ 一几面の傾斜が比較的に大きいが $w_{s t}$ を $0.1 \mathrm{~cm}$ と して奏際の勾配に換算す机体速度 $120 \mathrm{~km} / \mathrm{h}$ に於て 8 $0.2 \%$ に過ぎない。

\begin{tabular}{c|c|c|c|l|l}
\multicolumn{7}{|c}{ 表一3 } \\
\hline 速 度 & $\mathrm{km} / \mathrm{h}$ & 0 & \multicolumn{1}{|c|}{60} & \multicolumn{1}{|c|}{100} & \multicolumn{1}{|c}{120} \\
\hline$w_{0}$ & $w_{s t}$ & 1 & 1.042 & 1.124 & 1.156 \\
$\tan \theta_{0}$ & $\kappa w_{s t}$ & 0 & 0.0075 & 0.0897 & 0.1736 \\
$M_{0}$ & $M_{s t}$ & 1 & 1.049 & 1.093 & 1.097
\end{tabular}

(ii) 摩擦抵抗力の影響

路盤の深さが無限の時柱 (3.43), (3.44) 式心於て $h \rightarrow \infty$ と置けば摩擦抵抗力の影響のみ学考慮した場合の軌 道及び路盤の挵み運動赏あらわす式が得られる。

\section{6. 結論}

以上の計算に依つて車輛の通過特に於ける軌道の撓み量及びレールに生ずる四げモーメントは軌道及び路盤の 慣性学考慮することに依り多少增加すること知つた。この大きさほ $50 \mathrm{~kg}$ レール軗設の線路で速度 $100 \mathrm{~km} / \mathrm{h}$

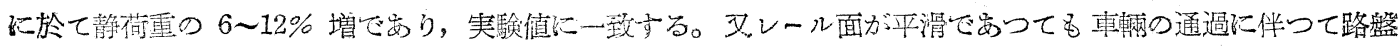

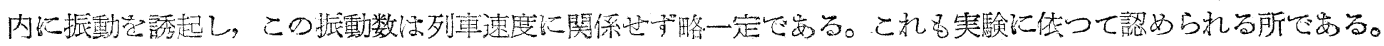

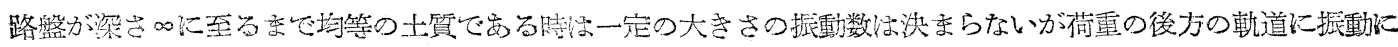
依るエネルギー恣残吉。

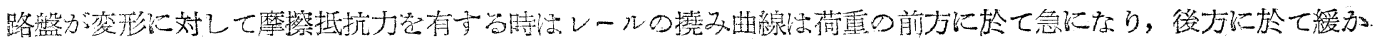

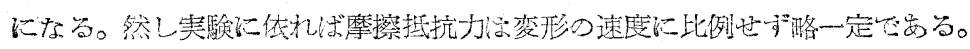

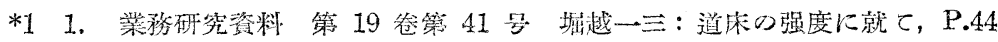

2. Transactions of the American Society of Mechanical Engineers, Vol.54 Stephen Timoshenko: Stresses in Railroad Tracks.

3. Organ für die Fortschritte des Eiscnbahnwesens, 90. Jahrgang, Heft 3 Artur Adler: Über Statik und Dynamik (Schwingungen) des Oberbaued.

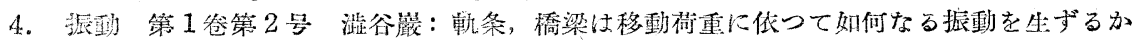

5. 日本機械学会論文集 第 15 爸第 50 号 穗坡衞:レールの動力学的問題の研究

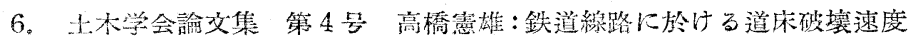

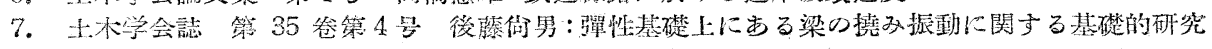

*2 本誦文では指数函数を多数使うので印刷の便宜上 $e^{x}$ を $\exp (x)$ を以てすらわすことつする

*3 寺沢賽一著 自然科学者のための数学概譣 4.10 计交函数系参照

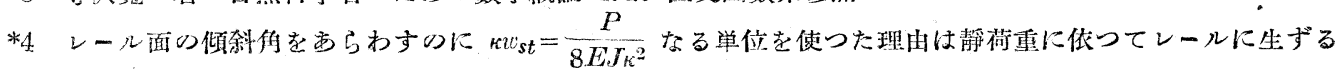

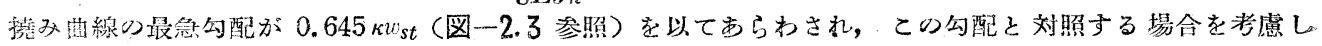
たためである。 